\title{
Caligus madeirensis sp. nov. (Copepoda: Caligidae) Parasitic on Pompano, Trachinotus ovatus (Linnaeus, 1758), from Eastern Atlantic Waters, Surrounding the Madeira Archipelago, Portugal
}

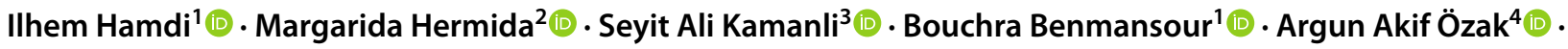 \\ Geoffrey Allan Boxshall ${ }^{5}$ (i)
}

Received: 28 April 2020 / Accepted: 22 September 2020 / Published online: 30 September 2020

(c) Witold Stefański Institute of Parasitology, Polish Academy of Sciences 2020

\begin{abstract}
Introduction A new species of the genus Caligus is described based on specimens collected from pompano, Trachinotus ovatus (Linnaeus), caught in eastern Atlantic waters, near the Madeira archipelago.

Methods Pompano $(n=21)$ were purchased from the local fish market and examined for parasitic copepods. Morphological features of the copepods were examined and drawn using an Olympus BX51 equipped with a drawing tube. Key diagnostic characters were scanned using a confocal laser scanning microscope and a scanning electron microscope.

Results Caligus madeirensis sp. nov., can be distinguished from all congeners (270 spp.) by the combination of the following characters: (i) an accessory process on the 3 outer terminal spines located on the distal exopodal segment of leg 1, (ii) a mandible with 14 teeth, (iii) a sternal furca with parallel, spatulate tines, (iv) a maxilliped with 2 simple setae at base of a claw, (v) a leg 3 with second endopodal segment with 5 pinnate setae, (vi) a 2-segmented leg 4 exopod with I; III spine formula, (vii) a male antenna with 4 overlapping plates on the distal segment, (viii) a male maxilliped corpus bearing a prominent myxal process ornamented with dense corrugations along inner margin.

Conclusion Together with Caligus madeirensis sp. nov., the Caligus fauna of Portugal consists of 13 species reported from 17 Portuguese marine fishes. Considering the large number of marine fish species $(510 \mathrm{spp}$.) currently recorded from Portuguese waters it seems that only $3.3 \%$ of the Portuguese marine fishes have been found to be infested with species of the genus Caligus O.F. Müller, 1758, the result of which, however, might be due to limited sampling.
\end{abstract}

Keywords Parasite $\cdot$ Copepod $\cdot$ Caligus $\cdot$ Portugal $\cdot$ Marine fish

Electronic supplementary material The online version of this article (https://doi.org/10.1007/s11686-020-00290-3) contains supplementary material, which is available to authorized users.

Argun Akif Özak

ozargun@gmail.com; ozargun@cu.edu.tr

Ilhem Hamdi

ilhemha@hotmail.fr

Margarida Hermida

margarida.hermida@mare-centre.pt

Seyit Ali Kamanli

alikamanli06@gmail.com

Bouchra Benmansour

Bouchrabenmansour85@gmail.com

Geoffrey Allan Boxshall

g.boxshall@nhm.ac.uk
1 Laboratory of Biodiversity, Parasitology and Ecology of Aquatic Ecosystems, Faculty of Sciences of Tunis, University of Tunis El Manar, 2092 Tunis, Tunisia

2 Oceanic Observatory of Madeira, Agência Regional Para O Desenvolvimento da Investigação Tecnologia E Inovação. Edifício Madeira Tecnopolo, Funchal, Portugal

3 Department of Biology, Faculty of Art and Science, Burdur Mehmet Akif Ersoy University, 15030 Burdur, Turkey

4 Department of Aquaculture and Fish Diseases, Faculty of Fisheries, Cukurova University, 01330 Sarıcam, Adana, Turkey

5 Department of Life Sciences, Natural History Museum, Cromwell Road, London SW7 5BD, UK 


\section{Introduction}

Among the 30 valid genera within the fish family Carangidae Rafinesque, the genus Trachinotus Lacepède currently comprises a total of 21 valid species. Pompano, T. ovatus (Linnaeus), is one of the most commonly cultured species of the genus Trachinotus which is mainly distributed in tropical and subtropical waters of the eastern Atlantic, the Mediterranean, and along the African coast, including the offshore islands [15]. Trachinotus ovatus has long been considered as one of the promising fish species for marine aquaculture due to its rapid growth rate and increasing market demand [41]. However, several bacterial and parasitic diseases have been reported in both wild and cultured T. ovatus which can cause significant economic losses [13, $14,16,32,35,42]$. Sea lice, species of parasitic copepods belonging to the family Caligidae Burmeister, 1835 often cause severe damage and lead to secondary bacterial infections on marine and brackish water fishes, and seven species of the genus Caligus O.F. Müller, 1785 (Copepoda: Caligidae) have been reported from five different fish species belonging to the genus Trachinotus. The first five Caligus species: Caligus epidemicus Hewitt, 1971, C. epinepheli Yamaguti, 1936, C. orientalis Gusev, 1951, C. pagrosomi Yamaguti, 1939, and C. punctatus Shiino 1955 have been reported from $T$. blochii (Lacepède). Whereas $C$. diaphanus von Nordmann, 1832 was reported from $T$. botla (Shaw), and C. mutabilis Wilson C.B., 1905 was reported from T. carolinus (Linnaeus), T. goodei Jordan \& Evermann, and T. ovatus (Linnaeus) [4, 9, 10, 18, 20, $24,31,34,40]$.

A review of the parasites of marine, freshwater and farmed fishes of Portugal, [11] listed eight species of the genus Caligus, C. brevicaudatus Scott, A., 1901, C. diaphanus, C. dicentrarchi Cabral \& Raibaut, 1983, C. elongatus von Nordmann, 1832, C. minimus Otto, 1821, C. musaicus Cavaleiro, Santos \& Ho, 2010, C. pageti Russel, 1925, and C. pelamydis Krøyer, 1863, from Portuguese marine fishes. However, according to [9], the holotype of Caligus biaculeatus Brian, 1914, collected by [1] and stored in the collections of the Musée Océanographique in Monaco, were recovered from the specimens of Macrurus and Bathygadus captured during a trawl operation conducted near Madeira archipelago. The report of $C$. biaculeatus from Madeira was presumably overlooked by [11]. Since this review [11], three more species: C. bonito Wilson, C.B. 1905, C. lichiae Brian, 1906 (as C. aesopus Wilson, C.B., 1921), and C. mulli Rodrigues, Özak, Silva \& Boxshall, 2018 have been reported from the fishes of Madeira and the Azores archipelago [5, 6, 17]. Thus, the total number of Caligus species reported from Portuguese marine fishes was increased from 8 to 12 . Here, we add one more species to the Caligus fauna of Portugal, Caligus madeirensis sp. nov., collected from T. ovatus captured from Madeira.

\section{Materials and Methods}

Twenty-one individuals of Trachinotus ovatus (Linnaeus, 1758) (total body length $27.1-40 \mathrm{~cm}$ ) caught in oceanic waters off Madeira, were purchased from local fishermen and examined for parasitic copepods. Copepods were removed from the host's body surface and fixed in 70\% ethanol. Subsequently, specimens were cleared in lactic acid for $2 \mathrm{~h}$ prior to examination using a Nikon SMZ $800 \mathrm{~N}$ dissecting stereomicroscope and an Olympus BX51 equipped with differential interference contrast (DIC) microscope. Specimens were mounted as temporary preparations in a drop of lactic acid on a cavity slide for making measurements and drawings. Measurements were made using an ocular micrometer and drawings were made with the aid of a drawing tube. All measurements are given in millimetres unless otherwise stated and are presented as the range followed by the mean in parentheses. Some appendages of the new species were scanned using a Zeiss LSM 700 Confocal laser scanning microscope (CLSM). CLSM images were processed using Drishti software (version 2.6.4) [23] by following the imaging techniques applied by [21]. The protocols for preparing crustaceans for scanning electron microscopy (SEM) followed [12]. Ethanolfixed specimens were hydrated to distilled water and postfixed in $1-2 \%$ osmium tetroxide (OsO4) in buffer for $2 \mathrm{~h}$, washed in distilled water, dehydrated through graded acetone series, critical point dried using liquid carbon dioxide as the exchange medium, mounted on aluminium stubs, and sputtercoated with platinum. Coated specimens were examined on a Zeiss Supra 55 (FE-SEM, Germany) field emission scanning electron microscope at $1-3 \mathrm{kV}$. The scientific and common names of fishes follow [15] and the morphological terminology for the copepods follows [2] and [19].

\section{Results}

Family: Caligidae Burmeister, 1835

Genus: Caligus O.F. Müller, 1785

Caligus madeirensis sp. nov. (6 females and 3 male).

Type host: Trachinotus ovatus (Linnaeus, 1758) (Carangidae).

Type locality: Eastern Atlantic waters, near Madeira (Portugal).

Site on host: Body surface. 
Prevalence: $38 \%$ ( 8 fish infected of a total of 21 examined).

Type material: Holotype female [CUMAPCOP/2019-8]; allotype male [CUMAPCOP/2019-9] temporarily stored in the collection of the Aquatic Parasitology Museum of the Faculty of Fisheries, University of Çukurova (CUMAP), Adana, Turkey due to Covid-19 and will be sent to the Natural History Museum in London, UK. Paratype female and male specimens are stored in the personal collection of the first author.

Etymology: The species name refers to the type locality.

\section{Description (Figs. 1-9).}

Adult female Body (Fig. 1a) typical for the genus with dorsal cephalothoracic shield, fourth leg bearing somite, genital complex, and 1-segmented abdomen. Total body length $4.74-4.94 \mathrm{~mm}(4.80, n=6)$ measured from midanterior margin of the frontal plate to the posterior end of caudal rami, excluding setae. Dorsal cephalothoracic shield, subcircular convex lateral margins, slightly longer than wide, $2.23-2.48 \times 2.00-2.20 \mathrm{~mm}(2.30 \times 2.12)$, anterior part ornamented with numerous sensillae; frontal plate with a strip of narrow marginal membrane forming a pair of lunules on either side; thoracic zone of shield wider than long $1.13-1.36 \times 1.42-1.58 \mathrm{~mm}(1.20 \times 1.50)$, about $52 \%$ of the cephalothorax, with posterior margin forming a pair of posterior sinuses on either side, each sinus bearing flaplike hyaline membrane, posterior edge of a thoracic zone extending slightly beyond the posterior end of lateral zones. Fourth pedigerous somite sub-trapezoidal, wider than long, $0.13-0.22 \times 0.48-0.54 \mathrm{~mm}(0.17 \times 0.50)$, distinctly separated from cephalothorax and genital complex. Genital complex wider than long, $1.26-1.39 \times 1.44-1.57 \mathrm{~mm}(1.31 \times 1.52)$, subrectangular with convex lateral margins and slightly lobate, rounded posterolateral corners, mid-anterior part about 1.21 times wider than the posterior part. Free abdomen (Fig. 1b), subrectangular, 1-segmented, longer than wide, $0.54-0.65 \times 0.37-0.48 \mathrm{~mm}(0.61 \times 0.42)$, with slightly indented anterolateral margin and convex lateral sides. Caudal ramus (Fig. 1b) subrectangular, about 1.6 times longer than wide $0.18-0.22 \times 0.11-0.14 \mathrm{~mm}(0.20 \times 0.12)$, about $33 \%$ of the abdomen, armed with 6 plumose setae plus tuft of spinules along inner margin, outer dorsal seta smallest, medio-dorsal surface of ramus ornamented with sensilla.

Antennule (Fig. 1c) 2-segmented; proximal segment with 25 plumose setae along anteroventral surface plus 2 naked dorsal setae, about 1.6 times longer than the distal segment; distal segment, cylindrical, about 2.6 times longer than wide, armed with 1 subterminal seta on posterior margin and 11 naked setae plus 2 aesthetascs around apex.
Antenna (Figs. 1d, 3a) uniramous, 3-segmented. proximal segment with posteriorly-directed blunt process, inner margin of process straight and outer margin rounded posteriorly; middle segment subrectangular, bearing large corrugated adhesion pad on dorsal surface; distal segment with sharply recurved claw, armed with distal seta located at mid-length and large, proximal cuticular swelling bearing tiny apical seta. Post-antennal process (Fig. 1e) with curved, blunt tine and armed with 2 unisensillate papillae on the basal part, plus similar unisensillate papilla located on the ventral cephalothoracic surface, near the base of postantennal process. Maxillule (Figs.1f, 3b) comprising anterior papilla carrying 3 naked setae and inwardly curved dentiform posterior process with rounded tip, medio-ventral surface of posterior process ornamented with traces of cuticular foldings. Mandible (Figs. 2a, 3c) stylet-like, armed with 14 inner teeth distally. Sternal furca (Figs. 2b, 3d) with subrectangular box and slightly divergent spatulate tines with incurved tips. Maxilla (Figs. 2c, 3d) 2-segmented, proximal segment (lacertus) large, unarmed; slender distal segment (brachium) bearing minute spinules distally along posterior margin (Figs. 2d, 3f), and with large subterminal hyaline membrane on inner margin plus short canna and long calamus distally; both canna and calamus ornamented with bilateral strips of serrated membranes. Maxilliped subchelate; protopodal segment (corpus) elongate and unarmed; distal subchela about 2 times longer than terminal claw and carrying two small setae at base of claw (Fig. 2f).

Leg 1 (Fig. 4a) biramous with 2-segmented exopod and unsegmented vestigial endopod. Sympod (Figs. 4a, 5a) bearing lateral plumose seta and inner plumose seta and ornamented with patch of tiny spinules on ventral surface (Figs. 5b, c). First exopodal segment robust and ornamented with a row of setules along the posterior margin; armed with a small spine at the outer distal corner. Distal exopodal segment (ESM_1) with 3 plumose setae posteriorly plus 4 terminal elements; outermost element (spine 1) with fine serrations along the outer margin (Fig. 4b, arrows), and slightly more than half length of spine 2 ; middle 2 elements (spines 2 and 3) more or less equal, each of 3 spines bearing slender, the spiniform accessory process slightly longer than spine (Fig. 5d, e, white arrows); innermost element (seta 4) (Fig. 5d, e, black arrows) slightly longer than spines.

Leg 2 (Fig. 4c) biramous, with distinct coxa and basis; coxa short, bearing long plumose inner seta and with sensillum on ventral surface; basis armed with short naked seta on outer distal corner plus extensive marginal membrane along the posterior margin and sensillum near mid-length of posterior margin. Exopod (Figs. 4c, 5f, g) (ESM_2) 3-segmented; first segment with inner plumose seta, outer spine sharply pointed with convex inner margin, extending beyond posterior margin of the second segment; with a row of setules on inner margin; second segment smallest, 

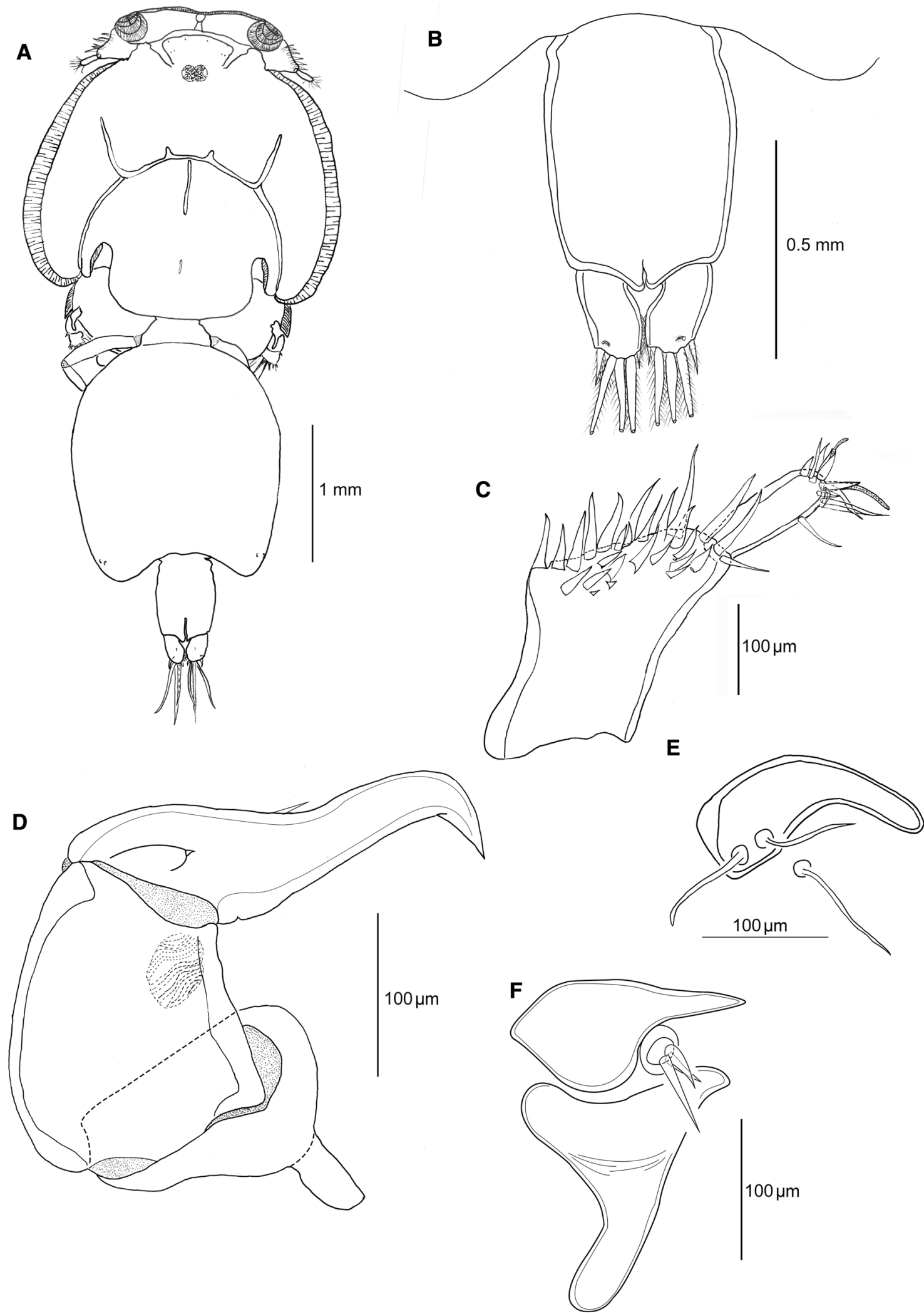

Fig. 1 Caligus madeirensis sp. nov. female. a Habitus (dorsal), b abdomen; $\mathbf{c}$ antennule; $\mathbf{d}$ antenna; e postantennal process; $\mathbf{f}$ maxillule 
Acta Parasitologica (2021) 66:361-376

365

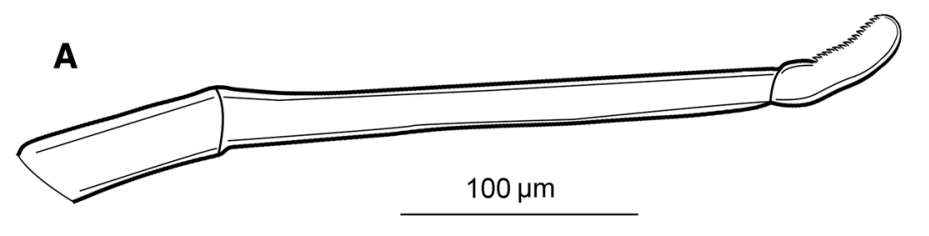

B
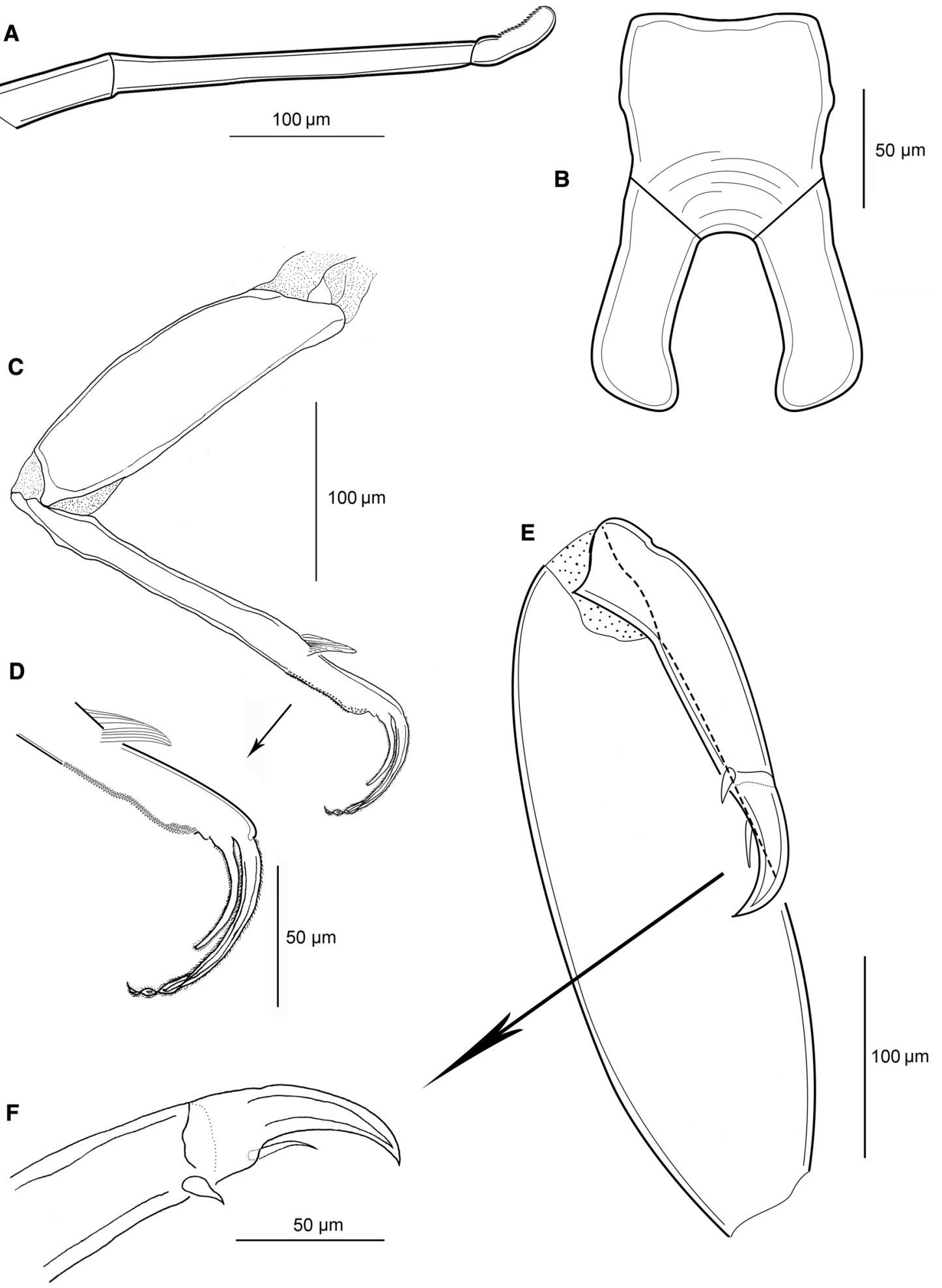

Fig. 2 Caligus madeirensis sp. nov. female. a Mandible; $\mathbf{b}$ asternal furca; $\mathbf{c}$ maxilla; $\mathbf{d}$ calamus and canna of maxilla; $\mathbf{e}$ Maxilliped; $\mathbf{f}$ setae at base of maxilliped claw

Springer 


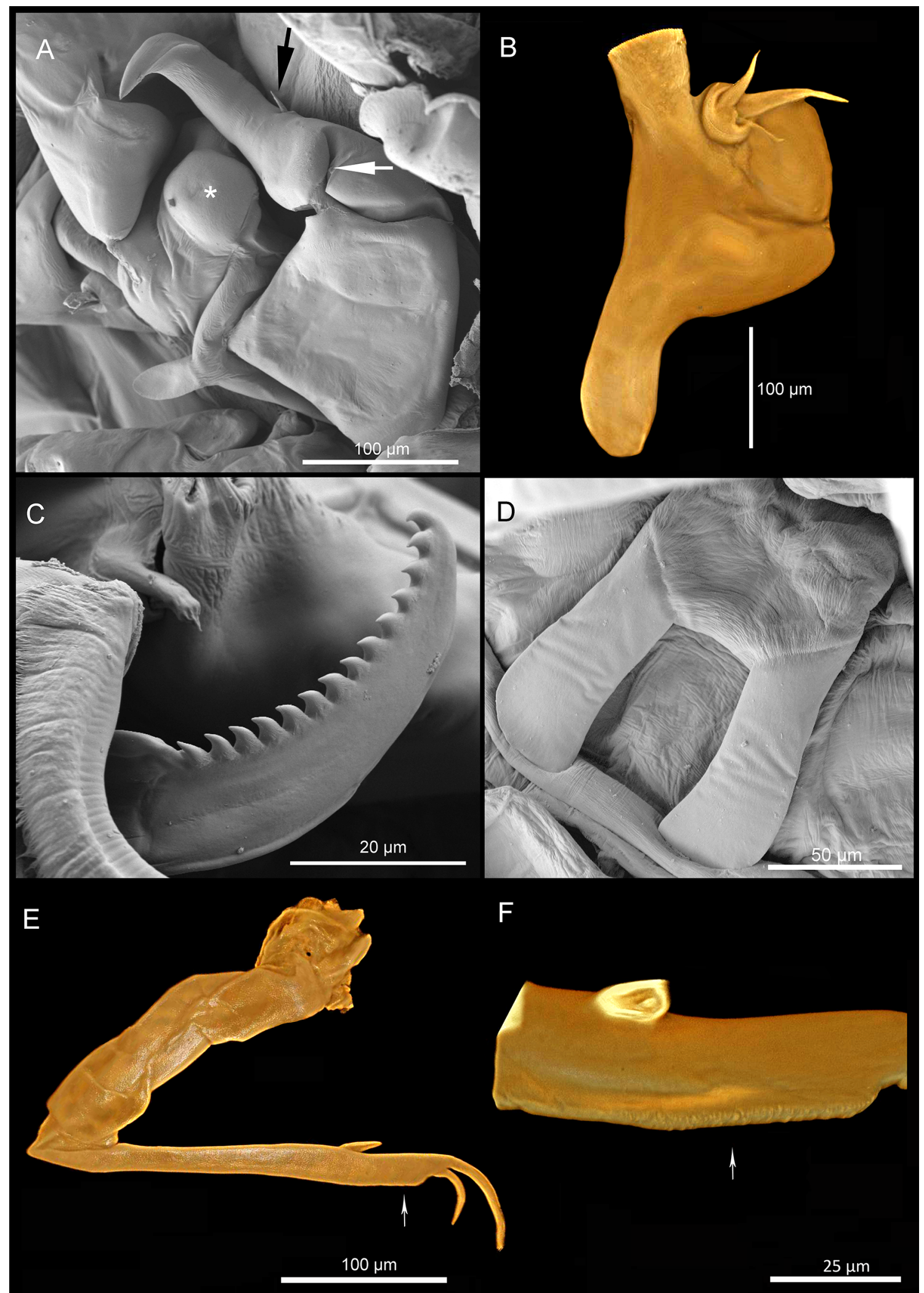

Fig. 3 Caligus madeirensis sp. nov. female. Scanning electron microscope (SEM) and Drishti applied confocal laser scanning microscope images (CLSM-D). a Antenna (SEM) with medio-distal seta (black arrow), proximal seta (white arrow), and semi-spherical cuticular pro- cess near antenna (asterisk); b maxillule (CLSM-D); $\mathbf{c}$ tip of mandible with 14 teeth (SEM); d sternal furca (SEM); e Maxilla (CLSMD); $\mathbf{f}$ Tiny denticles on the outer distal edge of brachium (CLSM-D) 


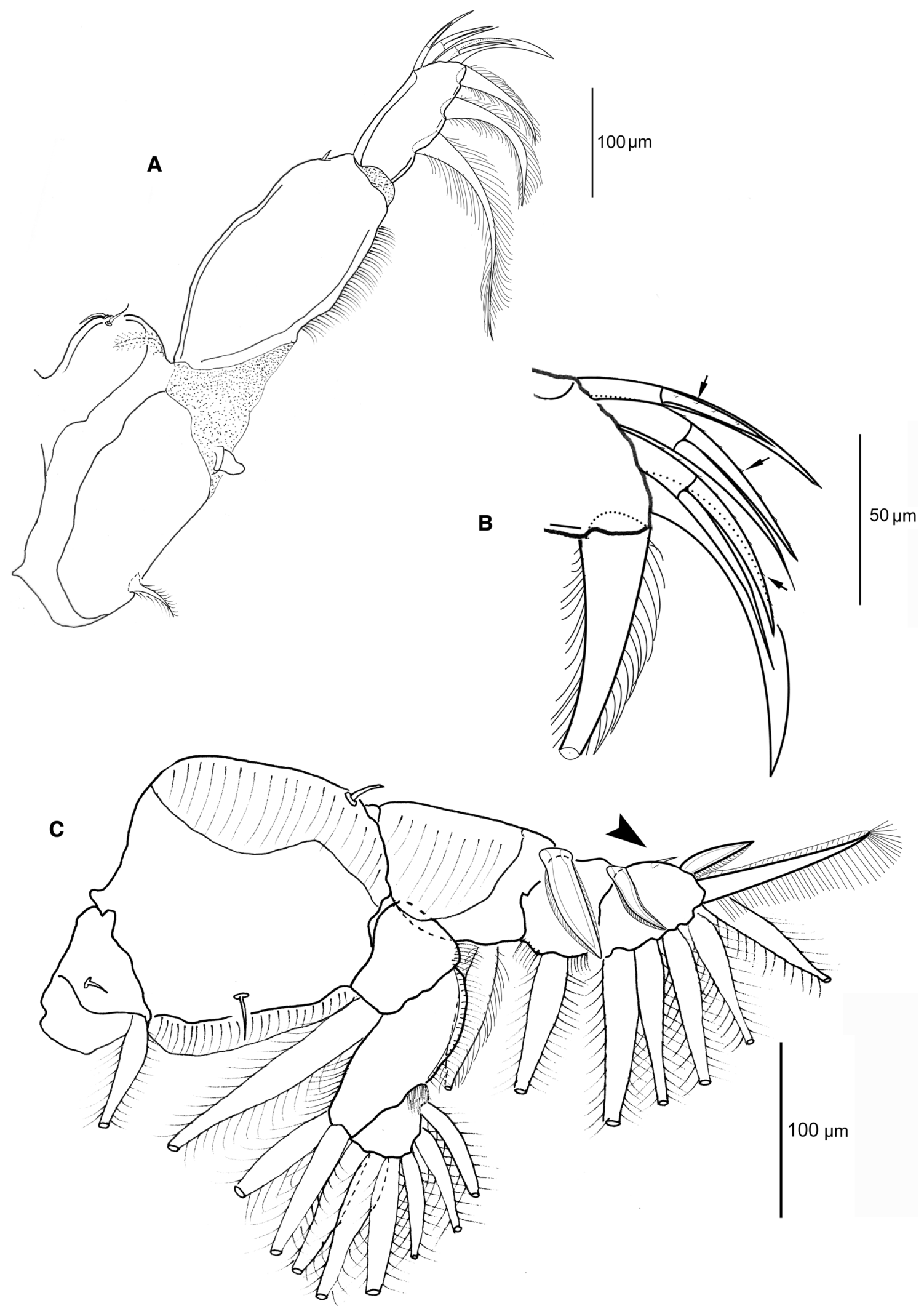

Fig. 4 Caligus madeirensis sp. nov. female. a Swimming leg 1; b Terminal elements on distal exopodal segment of leg 1 indicating tiny serrations on outer 3 spines (black arrows); c Leg 2 


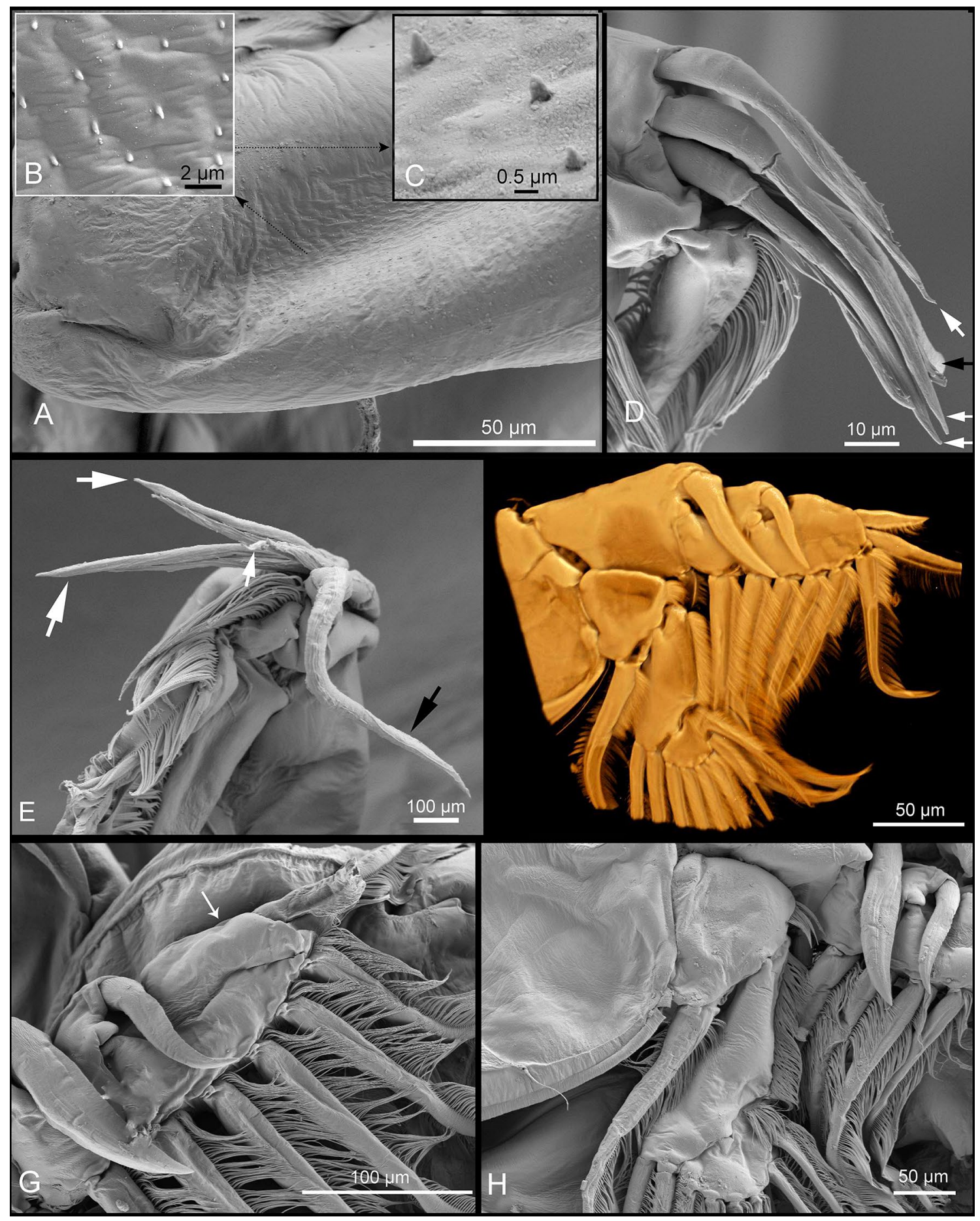

Fig. 5 Caligus madeirensis sp. nov. female. Scanning electron microscope (SEM) and Drishti applied confocal laser scanning microscope images (CLSM-D). a Ventral surface of leg 1 coxa (SEM); b spinules on ventral surface of leg 1 coxa (SEM); $\mathbf{c}$ the same at higher magnification (SEM); d outer 3 spines (white arrows) with accessory pro-

with inner plumose seta and outer distal spine slightly outwardly curved towards tip, extending obliquely across to posterior margin of third segment; spines on first and cesses and inner seta (black arrow) on distal exopodal segment of leg 1 (SEM); e the same from a different angle, $\mathbf{f}$ exopod and endopod of Leg 2 (CLSM-D), g leg 2 exopod, arrow indicating the first spine lying behind the distal exopodal segment (SEM); $\mathbf{h}$ endopodal segments of leg 2 (SEM)

second exopodal segments each with the bilateral hyaline membrane. Third exopodal segment with 3 outer spines and 5 inner plumose setae; first spine simple and smallest 
(Figs. 4c, 5g, arrows), lying parallel to the anterior margin of dorsal surface (ESM_2), second spine with flanges along the inner margin and third spine with outer marginal membrane and fine setules along inner margin. Endopod (Figs. 4c, 5h) 3-segmented; first segment subrectangular, bearing inner plumose seta and tuft of fine pinnules distolaterally; second segment elongate, armed with 2 inner plumose setae, and rows of fine spinules along outer edge; third segment smallest, with 6 distal plumose setae.

Leg 3 (Fig. 6a) with flattened apron-like sympod carrying extended strips of hyaline membrane along lateral and free posterior margins plus rows of spinules on the outer and mid-ventral surface. Exopod 3-segmented: the first segment with large, recurved outer spine; large hyaline flap present along concave margin of spine; second segment with outer spine and inner plumose seta; third segment with 3 subequal outer spines and 4 short pinnate setae. Endopod 2-segmented; first segment with long inner pinnate seta; second with 5 pinnate setae, ornamented with rows of long setules along the outer margin.

Leg 4 (Fig. 6b) uniramous. Protopodal segment with outer distal seta, outer dorsal surface ornamented with numerous sensillae. Exopod 2-segmented; first segment armed with long slender, bilaterally flanged, outer distal spine; second segment with 3 apical spines increasing in length from outer to inner, middle spine about 2 times longer than adjacent outer spine; each spine with pecten at base.

Spine (Roman numerals) and seta (Arabic numerals) formula of rami of legs $1-4$ as follows:

\begin{tabular}{lll}
\hline & Exopod & Endopod \\
\hline Leg 1 & I-0; III,1,3 & Vestigial \\
Leg 2 & I-1; I-1; II,I,5 & $0-1 ; 0-2 ; 6$ \\
Leg 3 & I-0; I-1; III,4 & $0-1 ; 5$ \\
Leg 4 & I-0; I,III & Absent \\
\hline
\end{tabular}

Leg 5 (Fig. 6c) located ventrally near posterolateral corners of the genital complex and represented by 2 papillae; outer papilla bearing single plumose seta; adjacent body surface to outer papilla ornamented with 3 sensillae; inner (exopodal) papilla carrying 2 subequal plumose setae.

Adult male (Fig. 6D) Total body length 5.05-5.50 mm $(5.30, n=3)$; cephalothoracic shield as long as wide $2.88-3.26 \times 2.86-3.27 \mathrm{~mm}(3.06 \times 3.07)$ excluding hyaline membranes. Thoracic zone of the shield wider than long and comprising about $53 \%$ of the length of cephalothorax. Fourth pedigerous somite wider than long $0.27-0.33 \times 0.68-0.72 \mathrm{~mm}(0.30 \times 0.70)$ and distinctly divided from cephalothorax and genital complex. Genital complex subrectangular, longer than wide, $0.97-1.1 \times 0.66-0.73 \mathrm{~mm}(1.00 \times 0.70)$ with parallel lateral margins and narrow posterior part, about
$33 \%$ of the length of cephalothorax. Abdomen 2-segmented; free abdominal somite quadrangular, as long as wide, $0.37-0.42 \times 0.37-0.43 \mathrm{~mm}(0.40 \times 0.40)$, with parallel lateral margins; anal somite longer than wide $0.47-0.52 \times 0.38-0.43 \mathrm{~mm}(0.50 \times 0.40)$, anal somite about 1.25 times longer than abdominal somite, the combined length of genital complex and entire abdomen about $63 \%$ of the length of cephalothorax. Caudal rami slightly longer than wide, $0.28-0.31 \times 0.68-0.72 \mathrm{~mm}(0.30 \times 0.20)$, about $60 \%$ of the length of the anal somite, carrying 6 plumose setae.

Antennule as in female. Antenna (Figs. 7a, 8a) 3-segmented; proximal segment elongate, with corrugated adhesion pad on medio-ventral surface; middle segment largest with corrugated pads on medial and distal surfaces (Figs. 7a, 8b) (ESM_3); posteriorly directed distal segment with 4 overlapping plates (Figs. 8a, b) (ESM_3), first (upper) plate smallest and ornamented with a slightly curved cuticular ridge (Fig. $8 \mathrm{C}$ ), second plate subrectangular with rounded corners, third plate (Figs. 8b, c) largest, with laterally directed subtriangular projection plus two cuticular ridges on medio-ventral surface, fourth (lower) plate (Fig. 8b, arrowhead) located just beneath medio-ventral surface of third plate, and armed with 2 slender basal setae. Post-antennal process (Fig. 7b) is more curved than that of females and with tapering tine. Maxillule with tiny denticle located medially on the posterior process (Figs. 7c, 9a, arrowed). Mandible and maxilla as in female. Maxilliped with massive corpus produced into the conspicuous subrectangular process on myxal area, opposing tip of the claw (Fig. 7d, 9b, c) (ESM_4); inner margin of myxal process covered with dense corrugations (Figs. 7E, 9C arrow). Subchela armed with 2 small setae at the base of the claw (Figs. 7E, 9D arrows) (ESM_4). Sternal furca and legs 1-4 as in female.

Leg 5 (Fig. 7f) represented by 2 papillae located on the posterolateral margin of the genital complex: outerpapilla with 1 plumose seta plus small and inner papilla with 2 plumose setae. Leg 6 (Fig. 7f) is represented by a single papilla on the posteroventral side of the genital complex, bearing 2 equal pinnate setae.

\section{Remarks}

The most distinguishing characteristics of the new species, C. madeirensis sp. nov, is the possession of an accessory process on all 3 outer terminal spines on the oblique distal margin of the second exopodal segment of leg 1. Including the three recently described new species, $C$. adanensis Özak, Sakarya \& Boxshall, 2019, C. chinglonglini Ohtsuka \& Boxshall, 2019, and C. kajii Ohtsuka \& Boxshall, 2019, the number of valid species within the genus Caligus is now 

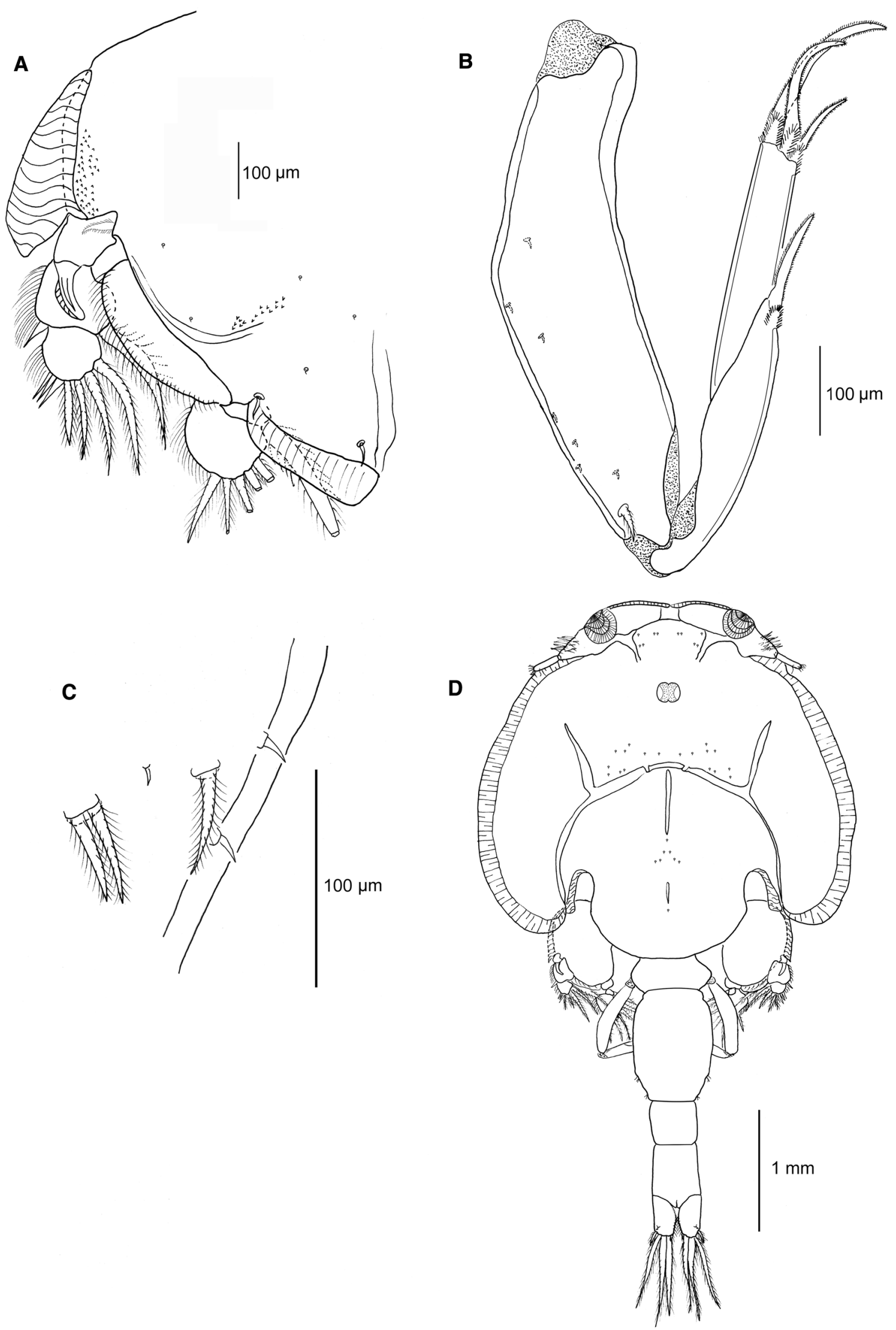

Fig. 6 Caligus madeirensis sp. nov. female. a Leg 3; b leg 4; c leg 5; d Caligus madeirensis sp. nov. male habitus (dorsal) 

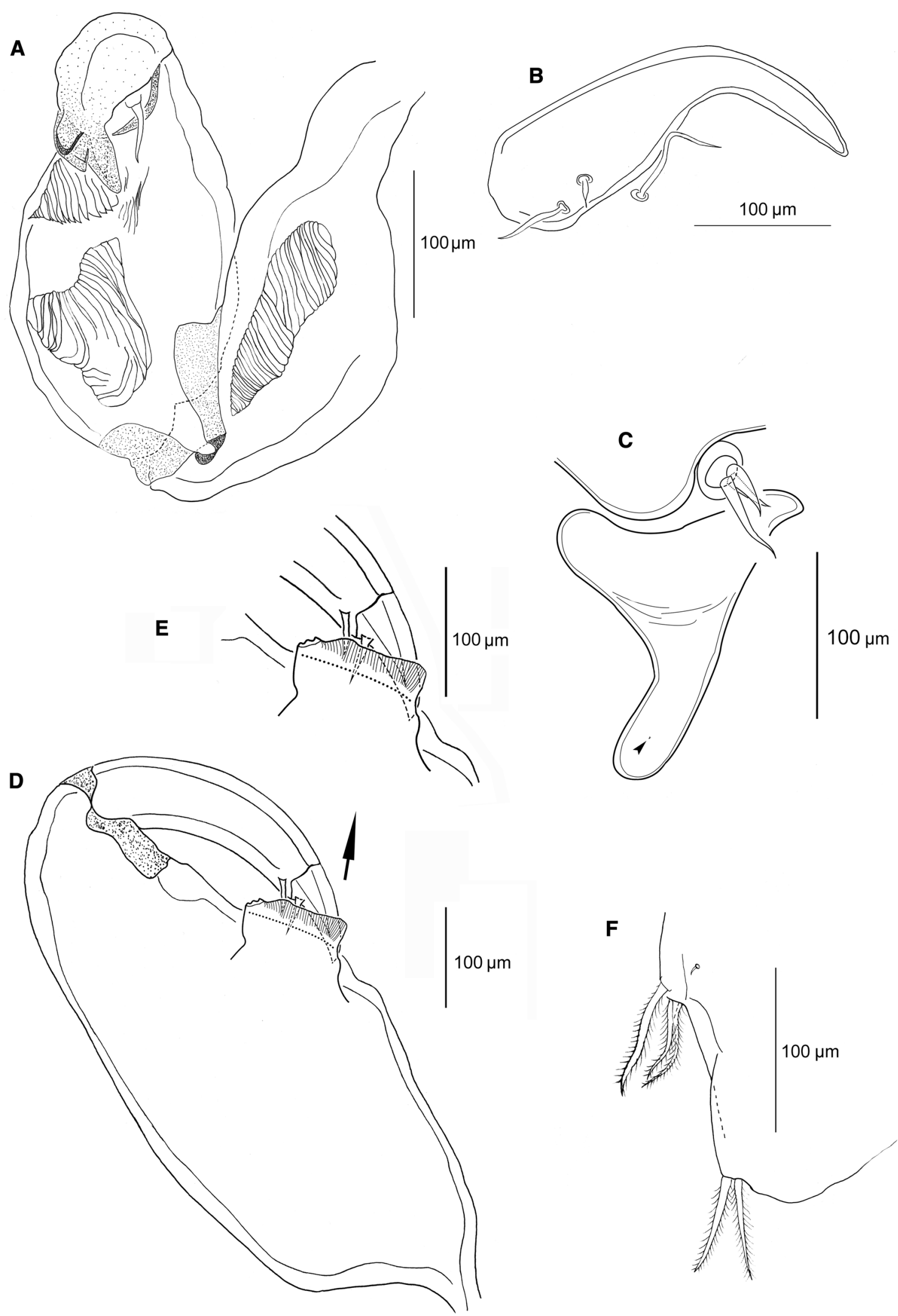

Fig. 7 Caligus madeirensis sp. nov. male. a Antenna; b postantennal process; c maxillule with tiny denticle (arrowhead) on the posterior dentiform process; $\mathbf{d}$ maxilliped; e myxal process on maxilliped corpus; $\mathbf{f}$ Leg 5 and Leg 6 
Fig. 8 Caligus madeirensis sp. nov. male. Scanning electron microscope (SEM) and Drishti applied confocal laser scanning microscope images (CLSM-D). a Antenna (SEM); b Middle and terminal segment of antenna indicating the lower plate (arrowhead) (CLSM-D); c upper 3 plates on the terminal segment of the antenna (SEM)

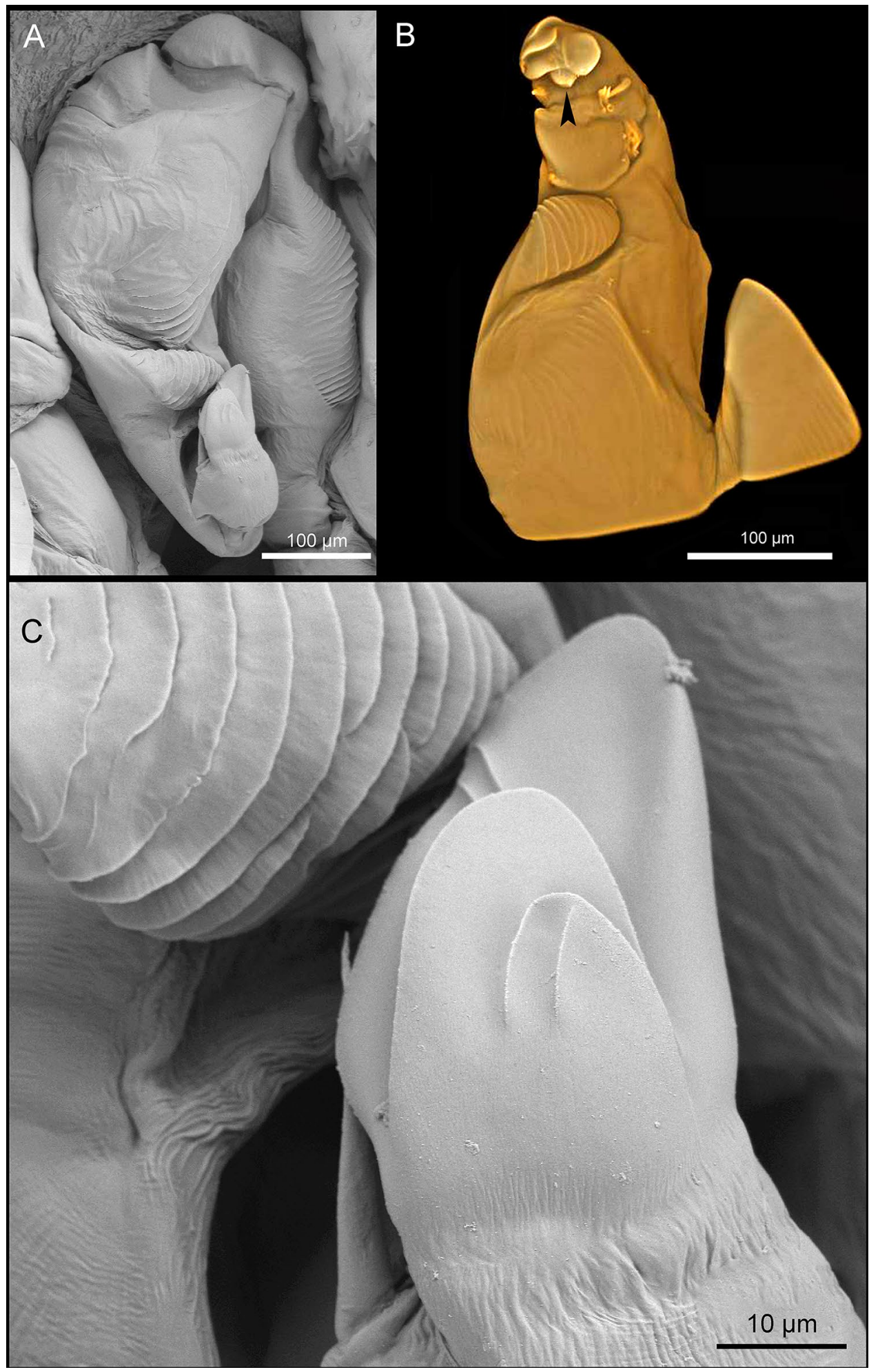

270 [30, 33]. To our knowledge, among these 270 species only the following four species: C. amblygenitalis Pillai, 1961, C. berychis Wilson C.B., 1936, C. rufimaculatus Wilson C.B., 1905, and C. sibogae Boxshall \& Gurney, 1980 share this unusual character state with $C$. madeirensis sp. nov.. Of these four species, $C$. amblygenitalis differs from the new species in having: (i) a female genital complex that is markedly longer than wide (vs. as long as wide) and with parallel (vs. convex) lateral margins, (ii) a female maxilliped with 2 laterally directed proximal projections (vs. none) on 
Fig. 9 Caligus madeirensis sp. nov. male. Scanning electron microscope (SEM) and Drishti applied confocal laser scanning microscope images (CLSM-

D). a Maxillule indicating tiny denticle (arrowhead) on the posterior dentiform process (SEM); b myxal process on maxilliped corpus; c corrugations (white arrow) along the inner margin of the myxal process on maxilliped corpus (SEM); $\mathbf{d}$ maxilliped claw with 2 setae at base (white arrows) (CLSM-D)

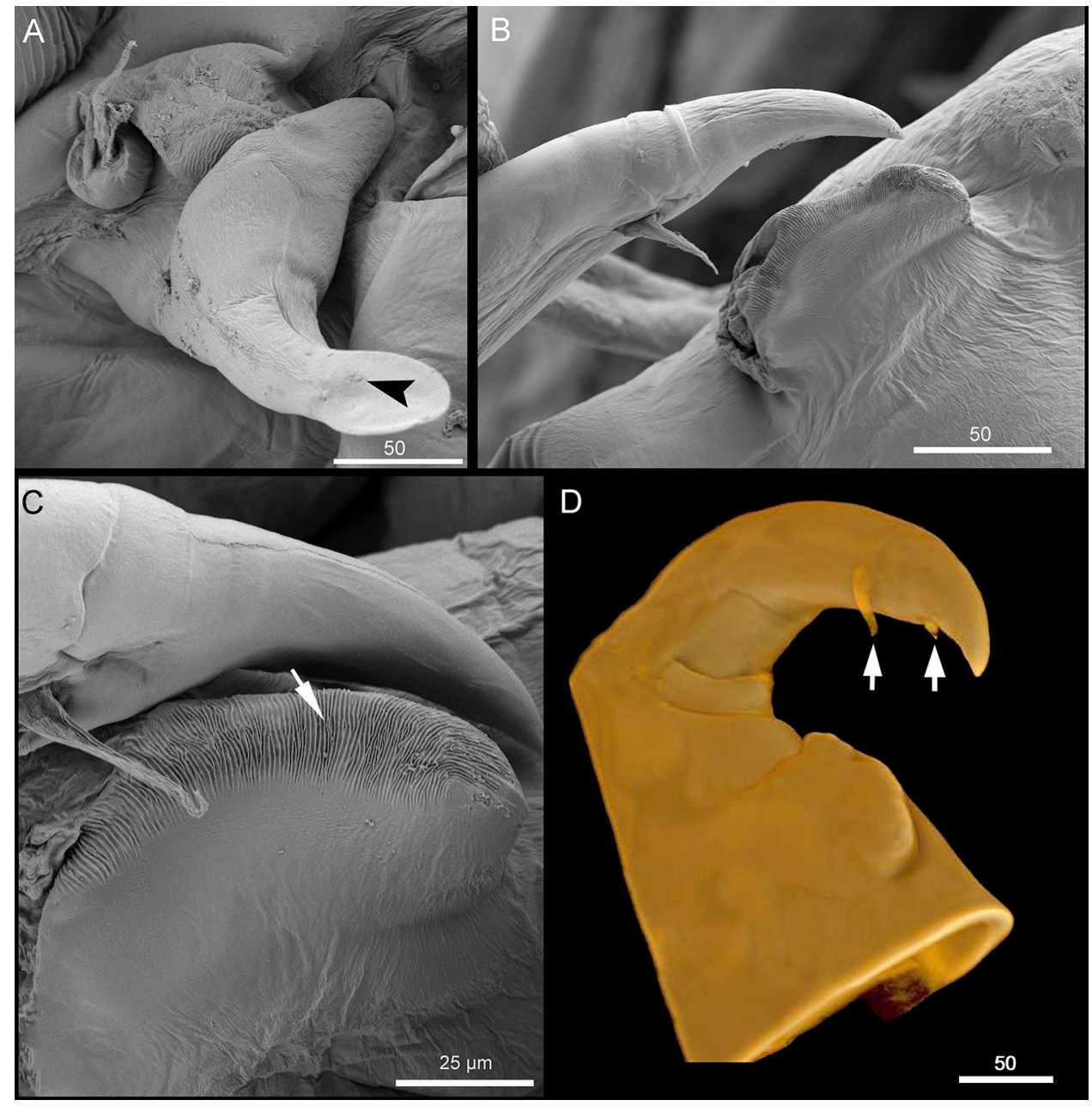

corpus, (iii) a mandible with 12 (vs. 14) marginal teeth at apex, (iv) a spine with markedly broad hyaline membrane along outer margin (vs. with bilateral narrow hyaline membrane) on middle exopodal segment of leg 2, and (v) a postmaxillary process (vs. none). Caligus berychis can be distinguished from $C$. madeirensis sp. nov. in having: (i) a female genital complex with distinctly lobate (vs. slightly lobate) posterolateral corners, (ii) a female abdomen that is as long as wide (vs. longer than wide), (iii) a female sternal furca with divergent (vs. more or less parallel) tines, (iv) a leg 4 exopod with I; IV (vs. I; III) spine formula, and (v) a male antenna with a single triangular claw-like plate on the distal segment (vs. 4 plates). Caligus rufimaculatus can be distinguished from the new species in having: (i) a female genital complex without lobate (vs. slightly lobate) posterolateral corners and with a straight (vs. concave) posterior margin, (ii) a straight (vs. curved) female postantennal process, (iii) a female sternal furca with divergent (vs. more or less parallel) tines, (iv) a leg 4 exopod with I; IV (vs. I; III) spine formula. Caligus sibogae differs from the new species in having: (i) a female abdomen slightly longer (vs. shorter) than the genital complex, (ii) a leg 2 with the first and second spines on the proximal and middle segments armed with small denticulations on inner margin (vs. armed with a bilateral strip of the hyaline membrane), (iii) a leg 3 with a straight spine (vs. curved) on the first exopodal segment, (iv) a male maxilliped with a single seta (vs. 2 seta) at the base of the claw.

In addition to the most remarkable feature (having an accessory process on all 3 outer terminal spines on the distal exopodal segment of leg 1), C. madeirensis sp. nov. can be distinguished from all other congeners of the combination of the following character states: (i) a mandible with 14 teeth, (ii) a sternal furca with more or less parallel, spatulate tines, (iii) a maxilliped with 2 simple setae at the base of the claw, (iv) a leg 3 with the second endopodal segment bearing 5 pinnate setae, (v) a 2-segmented leg 4 exopod with I; III spine formula, (vi) a male antenna with 4 overlapping plates on the distal segment, and (vii) a male maxilliped corpus bearing a prominent myxal process ornamented with dense corrugations along its inner margin. These detailed comparisons justify the establishment of a new species to accommodate the specimens collected from Trachinotus ovatus in the eastern Atlantic, off Madeira. 
Table 1 Species of Caligus reported from marine fishes of Portugal

\begin{tabular}{|c|c|c|c|c|}
\hline Species & Fish Family & Fish Species & Locations & References \\
\hline Caligus biaculeatus Brian, 1914 & Macrouridae & $\begin{array}{l}\text { Coryphaenoides sp. } \\
\text { (reported as Macrurus sp.) } \\
\text { Bathygadus sp. }\end{array}$ & Madeira & {$[1,9]$} \\
\hline Caligus bonito bonito Wilson C.B., 1905 & Scombridae & Katsuwonus pelamis (Linnaeus) & Madeira & [17] \\
\hline Caligus brevicaudatus Scott A., 1901 & Soleidae & $\begin{array}{l}\text { Pegusa lascaris (Risso) } \\
\text { Solea senegalensis Kaup } \\
\text { Solea solea (Linnaeus) }\end{array}$ & Mainland Portugal & {$[11,27-29]$} \\
\hline Caligus diaphanus von Nordmann, 1832 & Pleuronectidae & Platichthys flesus (Linnaeus) & Mainland Portugal & {$[7,11]$} \\
\hline Caligus dicentrarchi Cabral \& Raibaut 1983 & Moronidae & Dicentrarchus labrax (Linnaeus) & Mainland Portugal & {$[11,37]$} \\
\hline \multirow[t]{2}{*}{ Caligus elongatus von Nordmann, 1832} & Trichiuridae & Lepidopus caudatus (Euphrasen) & $\begin{array}{l}\text { Great Meteor Sea- } \\
\text { mount (Azores) }\end{array}$ & {$[11,22,26-29]$} \\
\hline & Soleidae & $\begin{array}{l}\text { Microchirus azevia (de Brito Capello) } \\
\text { Microchirus variegatus (Donovan) } \\
\text { Solea solea (Linnaeus) }\end{array}$ & Mainland Portugal & \\
\hline $\begin{array}{l}\text { Caligus lichiae Brian, } 1906 \\
\text { (reported as Caligus aesopus Wilson C.B., 1921) }\end{array}$ & Carangidae & $\begin{array}{l}\text { Seriola dumerili } \text { (Risso) } \\
\text { Seriola rivoliana } \text { Valenciennes }\end{array}$ & Madeira & {$[6]$} \\
\hline Caligus madeirensis sp. nov & Carangidae & Trachinotus ovatus (Linnaeus) & Maderia & Present account \\
\hline Caligus minimus Otto, 1821 & Moronidae & Dicentrarchus labrax (Linnaeus) & $\begin{array}{l}\text { Mainland Portugal } \\
\text { Farmed fish }\end{array}$ & $\begin{array}{l}{[11,37]} \\
{[11,38,39]}\end{array}$ \\
\hline $\begin{array}{l}\text { Caligus mulli Rodrigues, Özak, Silva \& Box- } \\
\text { shall, } 2018\end{array}$ & Mullidae & Mullus surmuletus Linnaeus & Azores & {$[36]$} \\
\hline Caligus musaicus Cavaleiro, Santos \& Ho, 2010 & Pleuronectidae & Platichthys flesus (Linnaeus) & Mainland Portugal & {$[8,11]$} \\
\hline Caligus pageti Russel, 1925 & Moronidae & Dicentrarchus labrax (Linnaeus) & Mainland Portugal & {$[11,37]$} \\
\hline Caligus pelamydis Krøyer, 1863 & $\begin{array}{l}\text { Scombridae } \\
\text { Carangidae }\end{array}$ & $\begin{array}{l}\text { Scomber scombrus Linnaeus } \\
\text { Trachurus trachurus (Linnaeus) }\end{array}$ & $\begin{array}{l}\text { Mainland Portugal } \\
\text { Mainland Portugal }\end{array}$ & {$[3,11,25]$} \\
\hline
\end{tabular}

\section{Discussion}

Including Caligus maderiensis sp. nov. from pompano, there are now 271 valid species of Caligus know from marine and brackish water fishes, but only 13 have been reported so far from Portuguese marine waters, utilizing 17 fish species belonging to eight fish families (Table 1). Considering the species richness of marine fish (510 spp.) currently known from Portuguese oceanic waters [15], it seems that the Caligus fauna of Portugal is relatively poorly known. Only $3.3 \%$ of Portuguese marine fishes have been found to be infested with species of Caligus and all of these are teleosts (Table 1). Of these fish species, the following eleven species: European seabass, Dicentrarchus labrax (Linnaeus), skipjack tuna, Katsuwonus pelamis (Linnaeus), surmullet, Mullus surmuletus Linnaeus, European flounder, Platichthys flesus (Linnaeus), Atlantic mackerel, Scomber scombrus Linnaeus, greater amberjack, Seriola dumerili (Risso), longfin yellowtail, S. rivoliana Valenciennes, Senegalese sole, Solea senegalensis Kaup, dover sole, S. solea (Linnaeus), pompano, Trachinotus ovatus, and Atlantic horse mackerel, Trachurus trachurus (Linnaeus) are economically important for Portuguese fisheries and marine aquaculture. In particular, greater amberjack, longfin yellowtail, pompano, and the two sole species listed, are considered as the most promising new species for marine fish farming. The sea lice reported from these economically important marine fish must be taken into consideration as one of the major disease threats that may result in mortalities and economic losses.

Acknowledgments We are extremely grateful to Prof. Selma ERAT (Head of the Advanced Technologies Research \& Application Center (MEITAM) of Mersin University, Mersin, Turkey), and all staff of MEITAM for providing access to Zeiss LSM 700 CLSM, Zeiss Supra 55 (FE-SEM) and their administrative and technical support during our studies. We also would like to thank Prof. Suphan KARAYTUĞ and Dr. Seher KURU (Department of Biology, Mersin University) for their hospitality and help during our stay at Mersin University, Mersin, Turkey. The authors are also grateful to Fernando Alexandre and the Direção Regional de Pescas members for their hospitality and help during the stay in Madeira, Portugal. We also wish to thank CIIMARMadeira for the internship invitation.

Funding This work was partially supported by the Ministry of Higher Education and Scientific Research of Tunisia and by the Oceanic Observatory of Madeira Project (M1420-01-0145-FEDER-000001Observatório Oceânico da Madeira-OOM). M.Hermida was financially supported by a post-doctoral grant from ARDITI (Regional Agency for Development of Research, Technology and Innovation of Madeira), Project M1420-09-5369-FSE-000001.

Availability of data and material (data transparency) All data generated or analyzed during this study are included in this published article (and its supplementary information files). 


\section{Compliance with ethical standards}

Conflict of interest The authors declare no conflict of interest and compliance with all relevant ethical standards.

Ethical approval Dead specimens of the Caligus species used herein, were collected from purchased dead fish samples caught by local fishermen. Therefore, this study was granted exemption from requiring ethics approval.

\section{References}

1. Brian A (1914) Copépodes parasites provenant des récentes campagnes scientifiques de S.A.S. le Prince Albert Ier de Monaco ou déposés dans les collections du Musée océanographie. Bull Inst Océanogr (Monaco) 286:1-14

2. Boxshall GA (1990) The skeletomusculature of siphonostomatoid copepods, with an analysis of adaptive radiation in structure of the oral cone. Philos Trans R Soc Lond B Biol Sci 328:167212. https://doi.org/10.1098/rstb.1990.0113

3. Castro S, Santos MJ (2013) Metazoan ectoparasites of Atlantic mackerel, Scomber scombrus (Teleostei: Scombridae): macroand microhabitat distribution. Parasitol Res 112:3579-3586. https://doi.org/10.1007/s00436-013-3543-8

4. Causey DL (1955) Parasitic Copepoda from Gulf of Mexico fish. Occas Pap Mar Lab LA State Univ 9:1-19

5. Cavaleiro B (2017) Metazoan parasites of skipjack tuna, Katsuwonus pelamis and Almaco jack, Seriola rivoliana, two important commercial species from Madeira archipelago, Portugal. Dissertation, Universidade do Porto, Portugal

6. Cavaleiro B, Hermida M, Saraiva A (2018) Parasites of amberjacks from the archipelago of Madeira, Eastern Atlantic. Dis Aquat Org 131:133-142. https://doi.org/10.3354/dao03294

7. Cavaleiro F, Santos MJ (2007) Survey of the metazoan ectoparasites of the European flounder Platichthys flesus (Linnaeus, 1758) along the north-central Portuguese coast. J Parasitol 93:1218-1222. https://doi.org/10.1645/GE-1071R1.1

8. Cavaleiro F, Santos MJ, Ho J (2010) Caligus musaicus n. sp. (Copepoda, Caligidae) parasitic on the European flounder, Platichthys flesus (Linnaeus) off Portugal. Crustaceana 83:457-464. https://doi.org/10.1163/001121610X489359

9. Cressey RF (1991) Parasitic copepods from the Gulf of Mexico and Caribbean Sea, III: Caligus. Smithson Contrib Zool 497:153. https://doi.org/10.5479/si.00810282.497

10. Dippenaar SM (2005) Reported siphonostomatoid copepods parasitic on marine fishes of southern Africa. Crustaceana 77(11):1281-1328. https://doi.org/10.1163/1568540043165985

11. Eiras JC (2016) Parasites of marine, freshwater and farmed fishes of Portugal: a review. Braz J Vet Parasitol Jaboticabal 25(3):259-278. https://doi.org/10.1590/S1984-29612016057

12. Felgenhauer B (1987) Techniques for preparing crustaceans for scanning electron microscopy. J Crustacean Biol 7:71-76

13. Fischthal JH (1980) Some digenetic trematodes of marine fishes from Israel's Mediterranean coast and their zoogeography, especially those from Red Sea immigrant fishes. Zool Scr 9(1/4):11-23

14. Fischthal JH, Thomas JD (1970) Digenetic trematodes of marine fishes from Ghana: Family Lepocreadiidae. J Helminthol 44(3/4):365-386

15. Froese R, Pauly D (2020) FishBase. https://www.fishbase.org. Accessed 13 Apr2020

16. Golvan YJ (1969) Systematique des Acanthocephales (Acanthocephala Rudolphi, 1801), L'ordre des Palaeacanthocephala
Meyer, 1931, La superfamille des Echinorhynchidea (Cobbold, 1876) Golvan et Houin 1973. Mém Mus Natl Hist Nat 47:1-373

17. Hermida M, Cavaleiro B, Gouveia L, Saraiva A (2018) Parasites of skipjack, Katsuwonus pelamis, from Madeira, Eastern Atlantic. Parasitol Res 117:1025-1103. https://doi.org/10.1016/j.fishr es.2019.04.010

18. Ho JS, Lin CL (2003) Solution to the taxonomic confusion surrounding Caligus epinepheli Yamaguti, a caligid copepod (Siphonostomatoida) parasitic on marine fishes. Zool Stud 42(2):268-283

19. Huys R, Boxshall GA (1991) Copepod evolution. The Ray Society, London

20. Johnson SC, Treasurer JW, Bravo S, Nagasawa K, Kabata Z (2004) A review of the impact of parasitic copepods on marine aquaculture. In: Hwang JS, Ho JS, Shih CT (eds) Proceedings of the 8th International Conference on Copepoda, Special Issue: Contemporary Studies on Copepoda. Zool Stud 43(2):229-243.

21. Kamanli SA, Kihara TC, Ball AD, Morritt D, Clark PF (2017) A 3D imaging and visualisation workflow, using confocal microscopy and advanced image processing for brachyuran crab larvae. J Microsc 266:307-323. https://doi.org/10.1111/jmi.12540

22. Klimpel S, Rückert S, Piatkowski U, Palm HW, Hanel R (2006) Diet and metazoan parasites of silver scabbard fish Lepidopus caudatus from the Great Meteor Seamount (North Atlantic). Mar Ecol Prog Ser 315:249-257. https://doi.org/10.3354/meps3 15249

23. Limaye A (2012) Drishti: a volume exploration and presentation tool. In: Stock SR (ed) Proceedings of SPIE Vol. 8506 SPIE. Developments in X-Ray Tomography VIII Bellingham, Washington

24. Luque JL, Cezar AD (2004) Metazoarios ectoparasitos do pampo galhudo, Trachinotus goodei Jordan \& Evermann, 1896 (Osteichthyes: Carangidae), do litoral do Estado do Rio de Janeiro. Brasil Acta Sci Biol 26(1):19-24

25. MacKenzie K, Campbell N, Mattiucci S, Ramos P, Pinto AL, Abaunza P (2008) Parasites as biological tags for stock identification of Atlantic horse mackerel Trachurus trachurus L. Fish Res 89(2):136-145. https://doi.org/10.1016/j.fishres.2007.09.031

26. Marques JF, Santos MJ, Cabral HN (2006) Soleidae macroparasites along the Portuguese coast: latitudinal variation and hostparasite associations. Mar Biol 150(2):285-298. https://doi. org/10.1007/s00227-006-0339-8

27. Marques JF, Teixeira CM, Cabral HN (2006) Differentiation of commercially important flatfish populations along the Portuguese coast: evidence from morphology and parasitology. Fish Res 81(2-3):293-305. https://doi.org/10.1016/j.fishres.2006.05.021

28. Marques JF, Santos MJ, Cabral HN (2009) Zoogeographical patterns of flatfish (Pleuronectiformes) parasites in the Northeast Atlantic and the importance of the Portuguese coast as a transitional area. Sci Mar 73(3):461-471. https://doi.org/10.3989/scima r.2009.73n3461

29. Marques JF, Santos MJ, Teixeira CM, Batista MI, Cabral HN (2011) Host-parasite relationships in flatfish (Pleuronectiformes): the relative importance of host biology, ecology and phylogeny. Parasitology 138(1):107-121. https://doi.org/10.1017/S0031 182010001009

30. Ohtsuka S, Boxshall GA (2019) Two new species of the genus Caligus (Crustacea, Copepoda, Siphonostomatoida) from the Sea of Japan, with a note on the establishment of a new species group. ZooKeys 893:91-113. https://doi.org/10.3897/zookeys.893.46923

31. Oldewage WH, Van As JG (1989) Occurrence and distribution of Caligus (Copepoda: Siphonostomatoida) in African coastal waters. Rev Zool Afric 103(1):91-98

32. Ou YJ, Ji L, Li JE, Fan CY, Wang G (2013) Correlation analysis of major morphometric traits and body weight of selective group 
at different month ages of Trachinotus ovatus. Shuichan Xuebao 37(7):961-969

33. Özak AA, Sakarya Y, Boxshall GA (2019) Caligus adanensis sp. nov. (Copepoda: Caligidae Burmeister, 1835) parasitic on garfish, Belone belone (Linnaeus, 1760), from the eastern Mediterranean Sea, off the Turkish coast. Mar Biodivers 49:1877-1890. https:// doi.org/10.1007/s12526-019-00949-9

34. Pillai NK (1967) Copepods parasitic on Indian marine fishes. A review. In: Proceedings of the Symposium on Crustacea. Symposium Series. Mar Biol Ass India 5(2):1556-1680

35. Raibaut A, Combes C, Benoit F (1998) Analysis of the parasitic copepod species richness among Mediterranean fish. In: Dahms HU, Glatzel T, Hirche HJ, Schiel S, Schminke HK (eds) Proceedings of the 6th International Conference on Copepoda. J Marine Syst 15(1/4):185-206

36. Rodrigues AMV, Özak AA, Silva LMH, Boxshall GA (2018) Caligus mulli n. sp. (Copepoda: Caligidae) parasitic on two Mullid fishes from the eastern Mediterranean and adjacent Atlantic waters. Parasitol Res 117:3843-3850. https://doi.org/10.1007/ s00436-018-6090-5

37. Santos MJ (1996) Observations on the parasitofauna of wild sea bass (Dicentrarchus labrax L.) from Portugal. Bull Eur Assoc Fish Pathol 16(3):77-79
38. Saraiva A, Costa J, Serrão J, Cruz C, Eiras JC (2015) A histologybased fish health assessment of farmed seabass (Dicentrarchus labrax L.). Aquaculture 448:375-381. https://doi.org/10.1016/j. aquaculture.2015.06.028

39. Saraiva A, Costa J, Serrão J, Eiras JC, Cruz C (2015) Study of the gill health status of farmed sea bass (Dicentrarchus labrax L., 1758) using different tools. Aquaculture 441:16-20. https://doi. org/10.1016/j.aquaculture.2015.02.004

40. Shiino SM (1955) A new piscicola copepod belonging to the genus Caligus from Matusima Bay. Bull Biogeogr Soc Jpn 16-19:135-140

41. Zhenzhen X, Ling X, Dengdong W, Chao F, Qiongyu L, Zihao L, Xiaochun L, Yong Z, Shuisheng L, Haoran L (2014) Transcriptome analysis of the Trachinotus ovatus: identification of reproduction, growth and immune-related genes and microsatellite markers. PLoS ONE 9(10):e109419. https://doi.org/10.1371/ journal.pone.0109419

42. Zhou YC, Zhu CH, Zhang B, Su YQ (2001) Isolation and prevention of the pathogen causing large scale death on Trachinotus ovatus. Mar Sci 25(4):40-44 